\title{
Effects of plot length and soil texture on runoff and sediment yield occurring on machine-trafficked soils in a mixed deciduous forest
}

\author{
Meghdad Jourgholami ${ }^{1}$ • Eric R. Labelle ${ }^{2}$
}

Received: 12 March 2019 / Accepted: 8 March 2020 / Published online: 16 March 2020

(C) INRAE and Springer-Verlag France SAS, part of Springer Nature 2020

\begin{abstract}
- Key message Runoff decreased significantly in each soil texture group, as plot length increased $(2-40 \mathrm{~m})$, whereas sediment yield showed an increasing trend. Runoff and sediment yield were higher in the clayey soil than in the loamy soil texture. - Context An important issue for decreasing the negative impact of ground-based skidding operations on the physical environment is the appropriate drainage of the surface flow away from the skid trail to decrease runoff and subsequent soil loss. Water diversion structures can be used to disperse the water from the trail to the stand but information on adequate spacing is lacking, especially when considering machine-trafficked forest soils.

- Aims The objective of this study was to quantify the effects of plot length $(2,5,10,20,30$, and $40 \mathrm{~m})$ and two soil texture types (clayey and loamy) on runoff and sediment yield in skid trails in a mixed deciduous forest in order to determine the ideal spacing between adjacent water diversion structures.

- Methods Runoff and sediment yield were measured for 25 rainfall events occurring over a 6-month period. The Pearson correlation was applied to determine the relationship among runoff, sediment yield, selected soil properties, plot length, soil texture, and canopy cover. In each soil texture group, runoff and sediment were plotted with rainfall intensity and plot length by a Gaussian polynomial regression model.

- Results Results show that plot length and soil texture significantly affected the amount of runoff and sediment yield. Plot length was positively and significantly correlated with sediment yield and negatively correlated with runoff. The highest runoff was found on the plot length of $2 \mathrm{~m}$ under clay soil by $1.49 \mathrm{~mm}$ followed by plot length of $5 \mathrm{~m}$ with clay by $1.15 \mathrm{~mm}$ and plot length of $2 \mathrm{~m}$ with loamy soil by $1.03 \mathrm{~mm}$. In both soil texture classes, the runoff decreased significantly, as plot length increased. Likewise, in each plot length tested, the values of runoff were higher in the clayey soil than in the loamy soil texture. Significantly higher values of sediment yield were found in the plot length of $40 \mathrm{~m}$ and $30 \mathrm{~m}$ under the clayey soil $\left(8.63 \mathrm{~g} \mathrm{~m}^{-2}\right.$ and $\left.6.84 \mathrm{~g} \mathrm{~m}^{-2}\right)$ followed by plot length of $40 \mathrm{~m}$ under loamy soil $\left(6.15 \mathrm{~g} \mathrm{~m}^{-2}\right)$. In each soil texture, sediment yield increased significantly, as plot length increased. Additionally, in each plot length, sediment yield was higher in the clayey soil than in the loamy soil texture.

- Conclusion The results of this study can be applied to mitigate the environmental impacts of ground-based skidding operations on skid trails and to determine the optimal distance of water diversion structure.
\end{abstract}

Keywords Soil disturbance $\cdot$ Skid trails $\cdot$ Soil protection $\cdot$ Mechanized harvesting

\section{Handling Editor: Barry A. Gardiner}

Contribution of the co-authors Meghdad Jourgholami prepared the major part of the manuscript text, statistical data processing, and interpretation. Meghdad Jourgholami and Eric R. Labelle prepared the application for data analysis and went through the whole mathematical process and data interpretation.

Meghdad Jourgholami

mjgholami@ut.ac.ir

Eric R. Labelle

eric.labelle@sbf.ulaval.ca
Department of Forestry and Forest Economics, Faculty of Natural Resources, University of Tehran, P.O. Box 31585-4314, Karaj, Alborz, Iran

2 Department of Wood and Forest Sciences, Université Laval, 2405 Rue de la Terrasse, Québec City G1V 0A6, Canada 


\section{Introduction}

Water infiltration rates in forest soils are generally very high and overland flow rarely occurs where an intact litter layer is present (MacDonald and Stednick 2003; Stuart and Edwards 2006). However, when a mechanical load is applied to the soil during ground-based skidding operations, soil particles are rearranged into a closer configuration, which results in an increased soil bulk density (Cambi et al. 2015; Jourgholami et al. 2019b) and reduced total porosity (Horn et al. 2004; Poltorak et al. 2018). Through this alteration, a decrease in saturated hydraulic conductivity and water infiltration occurs (Moore and Wondzell 2005; Ampoorter et al. 2011; Jourgholami et al. 2019a, b), which ultimately results in increased runoff and sediment yield (Sosa-Pérez and MacDonald 2017; Jourgholami et al. 2018a, b).

One of the most important factors influencing the degree of percolation of water into the soil is soil texture (Parsons et al. 2006; Holz et al. 2015). Texture also plays a key role in the detachment susceptibility of soil particles due to impacting raindrops. For example, Ekwue and Harrilal (2010) reported that the degree of splash detachment is positively correlated with clay content. Moreover, the cohesiveness and stability of particles is less in soils with low clay content than that of sand content (Jourgholami et al. 2019a).

Another important factor influencing runoff and sediment yield is slope length, which is defined as the length of the slope (or hillslope) or the distance from starting overland flow to the depositing location. Numerous studies have also been undertaken to characterize the effect of plot length on runoff and sediment yield in laboratory and field experiments under both artificial and natural rainfall conditions (Smets et al. 2008a; Nadal-Romero et al. 2011; Kinnell 2016; Zhang et al. 2018). By increasing slope length, the overland flow velocity increased, which results in an increased runoff energy and its ability to detach and transport soil particles (Wischmeier and Smith 1978). The type of soil erosion processes has also been linked to plot size (Smets et al. 2008b; Bagarello and Ferro 2010), where both rainsplash and sheetwash have been reported as the main erosion drivers in small plots (Prats et al. 2016). Moreover, the erosion process was shifted from splash erosion to rill and interrill erosion by increasing the scales from plot level to catchment level (Poesen et al. 1994; Prats et al. 2016). The scale dependency of runoff and sediment is a controversial issue due to the different surface conditions of the hillslope (Ghahramani et al. 2011).

Several studies have also found that the effects of increasing scale on the rates of sediment delivery showed controversial trends including a decrease of sediment yield, a constant to decreasing trend of sediment yield, and an increasing to decreasing sediment yield (Poesen et al. 1994; NadalRomero et al. 2011; de Vente et al. 2013). Likewise, Prats et al. (2016) reported that runoff was ten times higher in the micro-plots $\left(0.25 \mathrm{~m}^{2}\right)$ than in the larger plots $\left(100 \mathrm{~m}^{2}\right)$. Under simulated rainfall conditions, with plot lengths ranging from 1 to $20 \mathrm{~m}$, Xing et al. (2016) revealed that runoff rates decreased with an increase in plot length.

Thus far, many studies have reported the effects of groundbased skidding operations on runoff and sediment yield (Etehadi Abari et al. 2017; Jourgholami et al. 2018a, b) and efficacy of some post-harvest treatments (e.g., water diversion structures) to suppress these negative impacts (Jourgholami and Etehadi Abari 2017), but information on the effect of soil texture and plot length on runoff and sediment yield on skid trails remains scarce. Obtaining knowledge on scale effects on runoff and soil loss could facilitate finding the ideal spacing for installing water diversion structures on skid trails in order to reduce the environmental impacts after logging operations. Our main goal was to analyze the effects of different plot lengths and soil textures on runoff and sediment yield during the first 6 months after ground-based machine traffic on skid trails. We tested the hypothesis that plot length and soil texture may affect runoff and sediment yield during rainfall events.

\section{Material and methods}

\subsection{Site description}

The study site was established in an old-growth oriental beech stand in compartment no. 318 of Gorazbon district in the Kheyrud forest research station of the Hyrcanian forests, northern Iran (Fig. 1a). The research station lies between $51^{\circ}$ $33^{\prime} 12^{\prime \prime} \mathrm{E}$ and $51^{\circ} 39^{\prime} 56^{\prime \prime} \mathrm{E}$ longitude and $36^{\circ} 32^{\prime} 08^{\prime \prime} \mathrm{N}$ and $36^{\circ} 36^{\prime} 455^{\prime \prime} \mathrm{N}$ latitude. The size of the study area was 36.8 ha and the slope of the terrain ranged from 5 to $45 \%$ facing north. The study site has an elevation ranging from 1165 to $1240 \mathrm{~m}$ a.s.l and the mean annual precipitation is $1380 \mathrm{~mm}$, with the highest and smallest amounts occurring in October and July, respectively. The climate of the studied area is humid cold with a mean annual temperature of $7.9{ }^{\circ} \mathrm{C}$ with the hottest and coldest months in July and January, respectively. According to the USDA Soil Taxonomy, the soils are Alfisols with clay loam texture from limestone. The dominant forest stands are comprised of beech (Fagus orientalis Lipsky), accompanied with hornbeam (Carpinus betulus L.), velvet maple (Acer velutinum), and Caucasian alder (Alnus subcordata C.A.M.). The main herbaceous species are Cyclamen coum, Prunella vulgaris, Galium odoratum, Mercurialis perennis, Oplismenus undulatifolius, and Viola sieheana. Motor-manual tree felling was carried out by chainsaw in March 2016. The processed logs ranging from 6 to $11 \mathrm{~m}$ in length were skidded by a four-wheel Timberjack 450C skidder in May 2016. The important characteristics of the Timberjack $450 \mathrm{C}$ are as follows: an empty weight of 10.3 


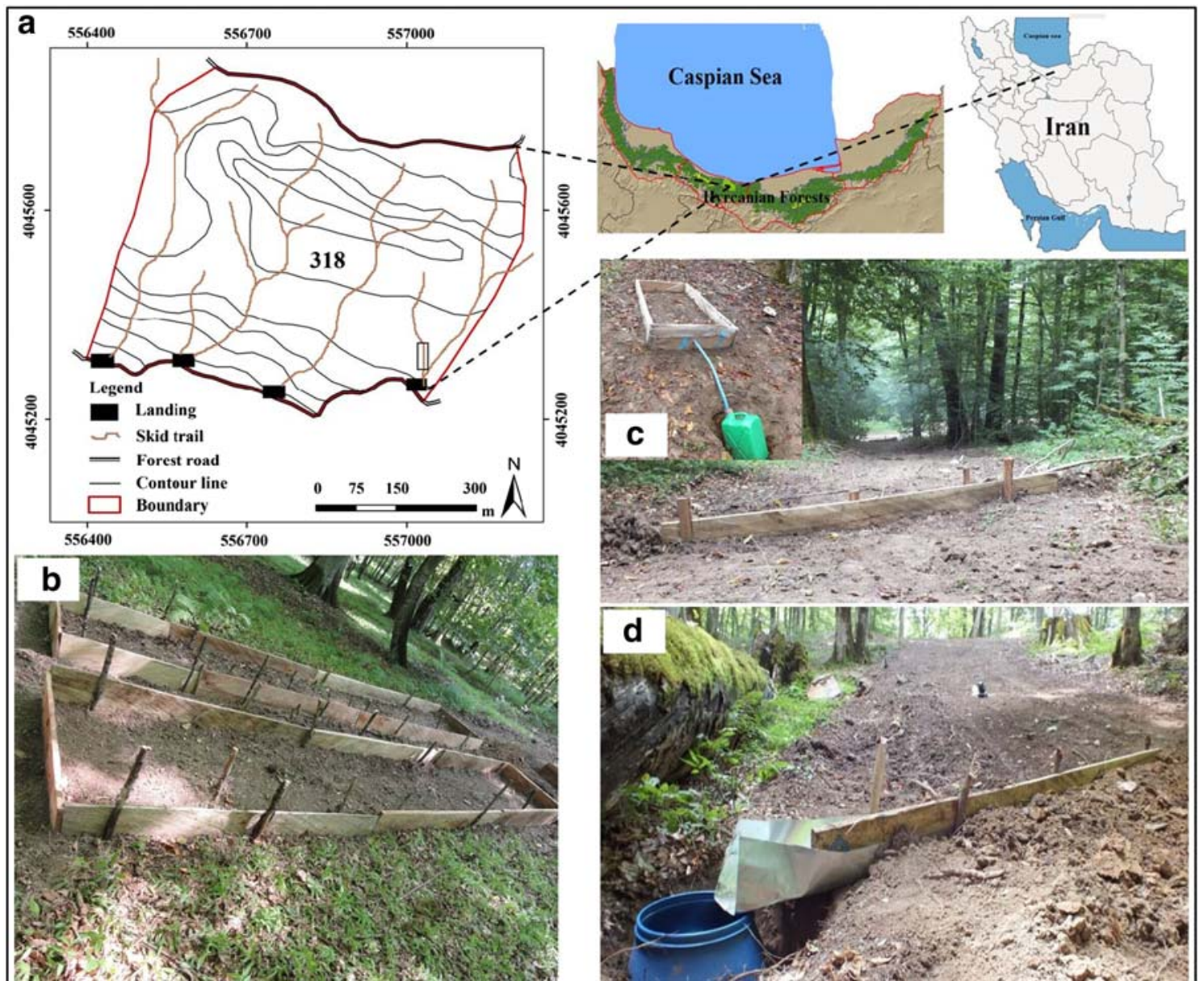

Fig. 1 The study area in Kheyrud forests in the Hyrcanian forests (a, UTM zone 39N, datum: European Datum 1950); plot length of 5 m (b); plot length of $2 \mathrm{~m}$ (c); and plot length of $40 \mathrm{~m}$ (d)

metric tons, tire inflation pressure of $220 \mathrm{kPa}$, average load volume of $2.9 \mathrm{~m}^{3}$, and the width of the skid trail set at $3.5 \mathrm{~m}$.

\subsection{Experimental design and measurements}

Six skid trails with a similar longitudinal slope (20-25\%) and exposed to high machine traffic (more than 15 machine cycles (i.e., a drive both empty and loaded of the skidder on the skid trails)) were selected following ground-based skidding operations for runoff plot establishment. Skid trails were mainly categorized in two soil classes based on soil texture (i.e., clayey or loamy) that was preselected by soil samples before plot establishment. In each soil texture group, runoff plots with width of $1 \mathrm{~m}$ and lengths of $2,5,10,20,30$, and $40 \mathrm{~m}$ were randomly established on the skid trails in triplicates (Fig. 1bd). During the 6-month study period (from 3 June 2016 to 20 November 2016), runoff volumes in each runoff plot were measured during 25 rainfall events occurring in the leafed period. Rainfall event is defined as a period of continuous rain, in which rainfall does not occur for at least $6 \mathrm{~h}$ after the measured event. Runoff is defined as the portion of the water cycle that flows away over the plot as overland flow instead of being infiltrated into soil. The perimeter of runoff plots was bounded by wooden boards inserted $20 \mathrm{~cm}$ inside the soil and extended $20 \mathrm{~cm}$ above the surface, thus acting as a containment measure to eliminate water in/to the plots. For the plots of 2-, 5-, and $10-\mathrm{m}$ lengths, runoff was collected and routed to a $0.05-\mathrm{m}^{3}$ storage tank whereas for plots with lengths longer than $10 \mathrm{~m}$, the runoff was collected and routed to a $0.20-\mathrm{m}^{3}$ storage tank. In both cases, storage tanks were located at the lower end of the plots. In this study, only surface runoff was measured and subsurface runoff was excluded. The stored runoff collected from the plots was manually measured for each runoff event. To determine sediment yield, a subsample of 11 for each runoff plot was taken after stirring the stored runoff, filtered through a filter paper with size of $2 \mu \mathrm{m}$, and oven-dried at $105^{\circ} \mathrm{C}$ for $24 \mathrm{~h}$, and then the sediment was weighed for each rainfall event. To determine the total amount of sediment yield in each rainfall event, the dry weighted sediments (in 11 runoff sample) were multiplied by the total amount of runoff collected in the storage tank. To characterize the runoff in millimeter and sediment yield in grams per square meter for each runoff event, the total amount of runoff and sediment yield were divided by the plot area. Three rainfall gauges were placed 
in an open area neighboring the stand (located less than $100 \mathrm{~m}$ away from the runoff plots) to measure gross rainfall. A manual rain collector (totalizer) with storage capacity of $200 \mathrm{~mm}$ was used to measure the amount of throughfall underneath the forest canopy within each runoff plot after each rainfall event. Runoff coefficient (RC) was estimated by Eq. 1 according to:

$\mathrm{RC}=\frac{\mathrm{RV}}{\mathrm{TR}}$

where

- $\quad \mathrm{RV}(\mathrm{mm})$ is the runoff volume

- $\quad$ TR $(\mathrm{mm})$ is the total rainfall

In each runoff plot, the variables including soil bulk density, total porosity, organic matter content, canopy cover, and soil particle size distribution were measured. Three soil samples were collected in each runoff plot with a length $\leq 10 \mathrm{~m}$, whereas an extra three soil samples were collected for every additional $10 \mathrm{-m}$ segment for plots that exceeded $10 \mathrm{~m}$ in length, thus totaling 216 soil samples. A steel cylinder (length of $40 \mathrm{~mm}$ and diameter of $56 \mathrm{~mm}$ ) was used to collect soil samples from the surface mineral soil of $0-10 \mathrm{~cm}$. Soil samples were placed in plastic bags, sealed, labeled, and transported to the laboratory. A portion of the soil samples was weighted after collecting and then after oven drying at $105{ }^{\circ} \mathrm{C}$ until a constant mass was reached to determine the moisture content and the soil bulk density. The hydrometer method was used to determine the soil particle size distribution for particles smaller than $0.075 \mathrm{~mm}$ (Gee and Bauder 1986) and the larger particles by sieving through a series of sieves of varying apertures. The wet sieving procedure was used to determine the aggregate stability (Kemper and Rosenau 1986). To assess soil particle density, the ASTM D854-00 2000 standard was applied and the formula as $\left(\mathrm{TP}=\left[1-\left(d_{\mathrm{s}} / d_{\mathrm{p}}\right)\right] \times 100\right)$ was used to determine total porosity (Jourgholami et al. 2018a). Soil organic $\mathrm{C}$ was determined by applying the Walkley-Black technique (Walkley and Black 1934). In three points at each runoff plots, an ocular observation was conducted to predict the canopy cover. In each soil texture group, runoff and sediment were plotted with rainfall intensity and plot length by a Gaussian polynomial regression model of the form Eq. (2):

$Y=a \times e^{-\frac{1}{2} \times\left(\frac{x_{1}-b}{c}\right)^{2}+\left(\frac{x_{2}-d}{e}\right)^{2}}$

where

- $\quad a, b, c, \ldots$ are the constant variables

- $\quad X_{1}$ and $X_{2}$ are the plot length (m) and rainfall intensity (mm; amount of rainfall per day), respectively.
A total of 450 data were collected (25 rainfall events $\times 6$ plot length treatments $\times 3$ replicates) in each soil texture type to depict runoff and sediment yield by a Gaussian polynomial regression model.

\subsection{Statistical analyses}

A factorial experiment with a complete block design was randomly assigned to the soil texture and plot length. The normality and homogeneity of variance were checked with the Kolmogorov-Smirnov and the Levene's test $(\alpha=0.05)$. Generalized linear models (GLM) were used to relate runoff and sediment yield to the independent factors including the plot length (i.e., 2, 5, 10, 20, 30, and $40 \mathrm{~m}$ ) and soil texture (clayey and loamy). In order to compare runoff and sediment yield among treatments including plot length, soil texture, and their interactions, a one-way analysis of variance (ANOVA) was performed. A post hoc test was used to verify the statistically significant differences between the treatments by the Tukey multiple range test at $P \leq 0.05$. The Pearson correlation was applied to determine the relationship among runoff, sediment yield, selected soil properties, plot length, soil texture, and canopy cover. The parameters were considered as a significant correlation when $P \leq 0.05$. All statistical tests were performed using the SPSS software package (release 17.0; SPSS, Chicago, IL, USA). The polynomial regression model was fitted to estimate the relationship between runoff and sediment yield with the rainfall intensity and plot length for both the clayey and loamy soil textures using the Curve Expert Professional 1.6 software.

\section{Results}

\subsection{Rainfall and plot characteristics}

In total, 25 rainfall events were measured during the study period. Individual rainfalls ranged in magnitude from 6.8 to $89.4 \mathrm{~mm}$ per day with an average of $35.4 \mathrm{~mm}$ per day. Total rainfall occurring during the study period was $885.7 \mathrm{~mm}$.

No significant differences were reported among soil bulk density, total porosity, organic matter, and canopy cover between soil texture groups for each plot length (Table 1). However, as targeted via the design of the experiment, significant differences in particle size distribution (percent of sand, silt, and clay) were detected between the two texture groups at each plot length (Table 1). The Pearson correlation analyses revealed that sediment yield was positively and significantly correlated with clay $(r=0.43, P<0.01)$, while being negatively correlated with runoff $(r=-0.37, P<0.05)$ and silt $(r=-$ $0.72, P<0.01$ ) (Table 2 ). Conversely, runoff was positively and significantly correlated with the runoff coefficient $(r=$ $0.81, P<0.01)$. Likewise, the plot length was positively and 
Table 1 Mean values ( \pm Std.) of different soil physical properties and canopy cover before the experiment started in 2016 in the runoff sample plots on different plot lengths (i.e., 2, 5, 10, 20, 30, and $40 \mathrm{~m}$ ) and soil textures (clay and loam)

\begin{tabular}{|c|c|c|c|c|c|c|c|c|}
\hline Plot length (m) & Soil texture & $\begin{array}{l}\text { Bulk density } \\
\left(\mathrm{Mg} \mathrm{m}^{-3}\right)\end{array}$ & Total porosity $(\%)$ & $\begin{array}{l}\text { Organic matter } \\
\text { content }(\%)\end{array}$ & $\begin{array}{l}\text { Canopy } \\
\text { cover }(\%)\end{array}$ & Sand $(\%)$ & Clay $(\%)$ & Silt (\%) \\
\hline \multirow[t]{2}{*}{2} & Clay & $1.29 \pm 0.02 \mathrm{a}$ & $50.3 \pm 0.8 \mathrm{a}$ & $3.41 \pm 0.19 \mathrm{a}$ & $81.6 \pm 2.9 \mathrm{a}$ & $20.3 \pm 2.1 \mathrm{a}$ & $43.0 \pm 2.0 \mathrm{a}$ & $36.7 \pm 1.5 \mathrm{a}$ \\
\hline & Loam & $1.32 \pm 0.03 \mathrm{a}$ & $49.3 \pm 1.3 \mathrm{a}$ & $4.15 \pm 1.9 \mathrm{a}$ & $80.0 \pm 5.0 \mathrm{a}$ & $29.3 \pm 1.5 b$ & $24.0 \pm 1.0 \mathrm{~b}$ & $46.7 \pm 1.5 b$ \\
\hline \multirow[t]{2}{*}{5} & Clay & $1.30 \pm 0.02 \mathrm{a}$ & $50.1 \pm 1.8 \mathrm{a}$ & $4.25 \pm 0.2 \mathrm{a}$ & $81.6 \pm 5.8 \mathrm{a}$ & $17.3 \pm 1.5 \mathrm{a}$ & $46.0 \pm 2.0 \mathrm{a}$ & $36.7 \pm 1.6 \mathrm{a}$ \\
\hline & Loam & $1.32 \pm 0.03 \mathrm{a}$ & $49.4 \pm 1.2 \mathrm{a}$ & $3.96 \pm 0.3 \mathrm{a}$ & $81.7 \pm 2.9 \mathrm{a}$ & $36.0 \pm 2.6 b$ & $23.0 \pm 2.0 \mathrm{~b}$ & $41.0 \pm 4.0 \mathrm{~b}$ \\
\hline \multirow[t]{2}{*}{10} & Clay & $1.29 \pm 0.02 \mathrm{a}$ & $50.3 \pm 1.6 \mathrm{a}$ & $4.32 \pm 0.6 \mathrm{a}$ & $76.7 \pm 2.9 \mathrm{a}$ & $19.0 \pm 2.7 \mathrm{a}$ & $50.3 \pm 1.5 \mathrm{a}$ & $30.7 \pm 1.2 \mathrm{a}$ \\
\hline & Loam & $1.32 \pm 0.08 \mathrm{a}$ & $49.4 \pm 3.1 \mathrm{a}$ & $4.06 \pm 0.1 \mathrm{a}$ & $80.0 \pm 5.0 \mathrm{a}$ & $42.0 \pm 2.7 b$ & $18.0 \pm 2.0 \mathrm{~b}$ & $40.0 \pm 1.0 \mathrm{~b}$ \\
\hline \multirow[t]{2}{*}{20} & Clay & $1.31 \pm 0.04 \mathrm{a}$ & $49.6 \pm 1.7 \mathrm{a}$ & $3.95 \pm 0.3 \mathrm{a}$ & $80.0 \pm 8.7 \mathrm{a}$ & $12.0 \pm 2.0 \mathrm{a}$ & $59.3 \pm 2.5 \mathrm{a}$ & $28.7 \pm 0.6 \mathrm{a}$ \\
\hline & Loam & $1.33 \pm 0.02 \mathrm{a}$ & $48.9 \pm 0.4 \mathrm{a}$ & $3.74 \pm 0.3 \mathrm{a}$ & $83.3 \pm 2.9 \mathrm{a}$ & $44.0 \pm 2.0 \mathrm{~b}$ & $13.7 \pm 1.5 b$ & $42.3 \pm 1.5 b$ \\
\hline \multirow[t]{2}{*}{30} & Clay & $1.32 \pm 0.03 \mathrm{a}$ & $49.4 \pm 1.2 \mathrm{a}$ & $3.78 \pm 0.1 \mathrm{a}$ & $76.7 \pm 2.9 \mathrm{a}$ & $12.0 \pm 2.0 \mathrm{a}$ & $64.0 \pm 2.0 \mathrm{a}$ & $24.0 \pm 4.0 \mathrm{a}$ \\
\hline & Loam & $1.30 \pm 0.04 \mathrm{a}$ & $49.9 \pm 1.6 \mathrm{a}$ & $3.83 \pm 0.3 \mathrm{a}$ & $81.7 \pm 7.6 \mathrm{a}$ & $48.7 \pm 1.5 b$ & $17.3 \pm 1.5 b$ & $34.0 \pm 3.0 \mathrm{~b}$ \\
\hline \multirow[t]{2}{*}{40} & Clay & $1.30 \pm 0.04 \mathrm{a}$ & $50.1 \pm 1.4 \mathrm{a}$ & $3.77 \pm 0.4 \mathrm{a}$ & $80.0 \pm 5.0 \mathrm{a}$ & $12.0 \pm 2.0 \mathrm{a}$ & $69.7 \pm 1.5 \mathrm{a}$ & $18.3 \pm 3.5 \mathrm{a}$ \\
\hline & Loam & $1.30 \pm 0.01 \mathrm{a}$ & $49.8 \pm 0.5 \mathrm{a}$ & $3.79 \pm 0.5 \mathrm{a}$ & $80.0 \pm 5.0 \mathrm{a}$ & $50.0 \pm 1.0 \mathrm{~b}$ & $11.0 \pm 1.0 \mathrm{~b}$ & $39.0 \pm 1.0 \mathrm{~b}$ \\
\hline
\end{tabular}

Note: Different letters after means within each treatment indicate significant differences by Tukey test $(P<0.05)$

significantly correlated with sediment yield $(r=0.80$, $P<0.01)$ and negatively correlated with runoff $(r=-0.70$, $P<0.01)$ and silt $(r=-0.56, P<0.01)$ (Table 2$)$.

\subsection{Runoff and sediment yield}

Results showed that plot length and soil texture significantly impacted the amount of runoff, sediment yield, and the runoff coefficient $(P<0.001)$. However, the interaction effect of plot length $\times$ soil texture was not significant concerning the amount of runoff, sediment yield, and the runoff coefficient (Table 3 ).

The highest amount of runoff was found on the plots of $2 \mathrm{~m}$ in length under clay soil $(1.49 \mathrm{~mm})$ followed by plots of $5 \mathrm{~m}$ with clay $(1.15 \mathrm{~mm})$ and plots of $2 \mathrm{~m}$ with loamy soil $(1.03 \mathrm{~mm})$. The smallest amounts of runoff were observed on plot lengths of 20,30, and $40 \mathrm{~m}$ under loamy soil (Table 4). In each soil texture group, runoff decreased significantly as plot length increased. Likewise, in each plot length, the runoff was higher in the clayey soil than in the loamy soil.

Table 2 Pearson correlations between runoff, sediment yield, targeted soil properties, plot length, soil texture, and canopy cover

\begin{tabular}{|c|c|c|c|c|c|c|c|c|c|c|c|}
\hline Variable & $\begin{array}{l}\text { Soil } \\
\text { texture }\end{array}$ & $\begin{array}{l}\text { Sediment } \\
\text { yield }\left(\mathrm{g} \mathrm{m}^{-2}\right)\end{array}$ & $\begin{array}{l}\text { Runoff } \\
(\mathrm{mm})\end{array}$ & $\begin{array}{l}\text { Runoff } \\
\text { coefficient }\end{array}$ & $\begin{array}{l}\text { Bulk density } \\
\left(\mathrm{Mg} \mathrm{m}^{-3}\right)\end{array}$ & $\begin{array}{l}\text { Total } \\
\text { porosity } \\
(\%)\end{array}$ & $\begin{array}{l}\text { Organic matter } \\
\text { content }(\%)\end{array}$ & $\begin{array}{l}\text { Canopy } \\
\text { cover }(\%)\end{array}$ & $\begin{array}{l}\text { Sand } \\
(\%)\end{array}$ & $\begin{array}{l}\text { Clay } \\
(\%)\end{array}$ & Silt (\%) \\
\hline Plot length (m) & $0.00^{\mathrm{ns}}$ & $0.80^{* *}$ & $-0.70^{* *}$ & $-0.47^{* *}$ & $-0.00^{\mathrm{ns}}$ & $0.00^{\mathrm{ns}}$ & $-0.24^{\mathrm{ns}}$ & $-0.08^{\mathrm{ns}}$ & $0.12^{\mathrm{ns}}$ & $0.14^{\mathrm{ns}}$ & $-0.56^{* *}$ \\
\hline Soil texture & 1 & $-0.29^{\mathrm{ns}}$ & $-0.42^{*}$ & $-0.52^{* *}$ & $0.21^{\mathrm{ns}}$ & $-0.21^{\mathrm{ns}}$ & $0.02^{\mathrm{ns}}$ & $0.18^{\mathrm{ns}}$ & $0.91^{* *}$ & $-0.93^{* *}$ & $0.71^{* *}$ \\
\hline $\begin{array}{l}\text { Sediment yield } \\
\left(\mathrm{g} \mathrm{m}^{-2}\right)\end{array}$ & & 1 & $-0.37^{*}$ & -0.15 & $0.02^{\mathrm{ns}}$ & $0.03^{\mathrm{ns}}$ & $-0.27^{\mathrm{ns}}$ & $-0.21^{\mathrm{ns}}$ & $-0.21^{\mathrm{ns}}$ & $0.43^{* *}$ & $-0.72^{* *}$ \\
\hline Runoff (mm) & & & 1 & $0.81^{* *}$ & $0.10^{\mathrm{ns}}$ & $0.10^{\mathrm{ns}}$ & $0.07^{\mathrm{ns}}$ & $-0.05^{\mathrm{ns}}$ & $-0.45^{* *}$ & $0.26^{\mathrm{ns}}$ & $0.15^{\mathrm{ns}}$ \\
\hline $\begin{array}{l}\text { Runoff } \\
\text { coefficient }\end{array}$ & & & & 1 & $-0.06^{\mathrm{ns}}$ & $0.06^{\mathrm{ns}}$ & $-0.01^{\mathrm{ns}}$ & $-0.17^{\mathrm{ns}}$ & $-0.58^{* *}$ & $0.44^{* *}$ & $-0.08^{\mathrm{ns}}$ \\
\hline $\begin{array}{l}\text { Bulk density } \\
\qquad\left(\mathrm{Mg} \mathrm{m}^{-3}\right)\end{array}$ & & & & & 1 & $-1.00^{\mathrm{ns}}$ & $0.09^{\mathrm{ns}}$ & $0.09^{\mathrm{ns}}$ & $0.15^{\mathrm{ns}}$ & $-0.15^{\mathrm{ns}}$ & $0.03^{\mathrm{ns}}$ \\
\hline $\begin{array}{l}\text { Total porosity } \\
\text { (\%) }\end{array}$ & & & & & & 1 & $-0.09^{\mathrm{ns}}$ & $-0.08^{\mathrm{ns}}$ & $-0.15^{\mathrm{ns}}$ & $0.15^{\mathrm{ns}}$ & $-0.13^{\text {ns }}$ \\
\hline $\begin{array}{l}\text { Organic matter } \\
\text { content }(\%)\end{array}$ & & & & & & & 1 & $-0.13^{\mathrm{ns}}$ & $-0.08^{\mathrm{ns}}$ & $0.00^{\mathrm{ns}}$ & $0.13^{\mathrm{ns}}$ \\
\hline $\begin{array}{l}\text { Canopy cover } \\
(\%)\end{array}$ & & & & & & & & 1 & $0.19^{\mathrm{ns}}$ & $-0.24^{\mathrm{ns}}$ & $0.27^{\mathrm{ns}}$ \\
\hline Sand $(\%)$ & & & & & & & & & 1 & $-0.95^{* *}$ & $0.62^{* *}$ \\
\hline Clay (\%) & & & & & & & & & & 1 & $-0.83^{* *}$ \\
\hline Silt (\%) & & & & & & & & & & & 1 \\
\hline
\end{tabular}

Note: ${ }^{*} P<0.05 ;{ }^{* *} P<0.01 ; n s$, not significant 
Table 3 ANOVA for the effect of plot length, soil texture, and their interactions on runoff and sediment yield

\begin{tabular}{|c|c|c|c|c|c|c|c|}
\hline \multirow[t]{2}{*}{ Source } & \multirow[t]{2}{*}{ d.f. } & \multicolumn{3}{|l|}{$F$} & \multicolumn{3}{|l|}{$P$ value } \\
\hline & & $\begin{array}{l}\text { Runoff } \\
(\mathrm{mm})\end{array}$ & $\begin{array}{l}\text { Sediment } \\
\text { yield }\left(\mathrm{g} \mathrm{m}^{2}\right)\end{array}$ & $\begin{array}{l}\text { Runoff } \\
\text { coefficient }\end{array}$ & Runoff & $\begin{array}{l}\text { Sediment } \\
\text { yield }\end{array}$ & $\begin{array}{l}\text { Runoff } \\
\text { coefficient }\end{array}$ \\
\hline Plot length & 5 & 47.91 & 36.55 & 104.59 & $\leq 0.001^{* *}$ & $\leq 0.001^{* *}$ & $\leq 0.001^{* *}$ \\
\hline Soil texture & 1 & 65.74 & 23.15 & 123.88 & $\leq 0.001^{* * *}$ & $\leq 0.001^{* * *}$ & $\leq 0.001^{* *}$ \\
\hline $\begin{array}{l}\text { Plot length } \times \\
\text { soil texture }\end{array}$ & 5 & 0.92 & 1.46 & 2.07 & $0.47^{\mathrm{ns}}$ & $0.20^{\mathrm{ns}}$ & $0.07^{\mathrm{ns}}$ \\
\hline
\end{tabular}

Note: $* P<0.05 ; * * P<0.01 ; n s$, not significant
Runoff in the plot length of $2 \mathrm{~m}$ under the clay and loam soil was 4.4 and 9.6 times higher than what was recorded in the plot length of $40 \mathrm{~m}$ (Table 4).

Significantly higher values of sediment yield were found in plot lengths of $40 \mathrm{~m}$ and $30 \mathrm{~m}$ under the clayey soil (8.63 $\mathrm{g} \mathrm{m}^{-2}$ and $6.84 \mathrm{~g} \mathrm{~m}^{-2}$ ) followed by a plot length of $40 \mathrm{~m}$ under loamy soil $\left(6.15 \mathrm{~g} \mathrm{~m}^{-2}\right)$, while the smallest amounts of sediment yield were detected at plot lengths of $2 \mathrm{~m}$ and $5 \mathrm{~m}$ under the loamy soil. In each soil texture group, the sediment yield increased significantly as the plot length increased. Additionally, in each plot length, the sediment yield was higher in the clayey soil than in the loamy soil. By increasing the plot length, sediment yield values in the plots of 5-, 10-, 20-, 30-, and 40-m lengths under the clayey soil were increased by $24 \%, 52 \%, 104 \%, 210 \%$, and $290 \%$, compared with the plot length of $2 \mathrm{~m}$, respectively (Table 4). A similar trend (increases in sediment yield as plot length increases) was also observed under the loamy soil texture. Sediment yields in the plot length of $40 \mathrm{~m}$ under the clay and loam soil were 3.9 and 3.8 times higher than the plot with a length of $20 \mathrm{~m}$ (Table 4). The highest values of runoff coefficient were detected in plot lengths of $2 \mathrm{~m}$ and $5 \mathrm{~m}$ with clayey soil. By increasing plot length, the runoff coefficient decreased in each soil texture group (Table 4).
Based on the regression analysis, in both clay and loam soil textures, runoff and runoff coefficient significantly decreased as a logarithmic function as plot length increased (Fig. 2a, c). In addition, the regression analysis demonstrated that sediment yield logarithmically increased by increasing plot length (Fig. 2b). Based on the regression analysis, a significant positive linear relationship was found between runoff and runoff coefficient for both clay- and loam-textured soils (Fig. 3).

\subsection{Runoff and sediment yield model}

Results of the Gaussian polynomial regression model for the relationship between runoff and sediment yield, rainfall intensity (RI; amount of rainfall per day), and plot length (PL) were as follows (Eqs. 3-6):

Runoff model for clayey soil texture:

Runoff $_{\text {clay }}=1970889.01 \times e^{-\frac{1}{2} \times\left(\frac{\mathrm{PL}+620.68}{121.29}\right)^{2}+\left(\frac{\mathrm{RI}-89.56}{-36.5}\right)^{2}}$

Runoff model for loamy soil texture:

Runoff $_{\text {loam }}=4898419.66 \times e^{-\frac{1}{2} \times\left(\frac{\mathrm{PL}+287.41}{54.02}\right)^{2}+\left(\frac{\mathrm{RI}-96.58}{-39.2}\right)^{2}}$
Table 4 Mean ( \pm Std. error) of runoff, sediment yield, and runoff coefficient on different plot lengths (i.e., 2, 5, 10, 20, 30, and $40 \mathrm{~m}$ ) and soil textures (clay and loam). Different letters indicate significant differences at $P<0.05$

\begin{tabular}{lllll}
\hline Plot length $(\mathrm{m})$ & Soil texture & Runoff $(\mathrm{mm})$ & Sediment yield $\left(\mathrm{g} \mathrm{m}^{2}\right)$ & Runoff coefficient \\
\hline 2 & Clay & $1.49 \pm 0.15 \mathrm{a}$ & $2.21 \pm 0.02 \mathrm{e}$ & $0.035 \pm 0.003 \mathrm{a}$ \\
& Loam & $1.03 \pm 0.11 \mathrm{~b}$ & $1.63 \pm 0.03 \mathrm{e}$ & $0.024 \pm 0.002 \mathrm{~b}$ \\
5 & Clay & $1.15 \pm 0.13 \mathrm{ab}$ & $2.74 \pm 1.12 \mathrm{~d}$ & $0.026 \pm 0.002 \mathrm{ab}$ \\
& Loam & $0.63 \pm 0.08 \mathrm{~cd}$ & $1.88 \pm 1.18 \mathrm{e}$ & $0.014 \pm 0.001 \mathrm{~cd}$ \\
10 & Clay & $0.83 \pm 0.10 \mathrm{bc}$ & $3.36 \pm 0.28 \mathrm{~d}$ & $0.018 \pm 0.002 \mathrm{bc}$ \\
& Loam & $0.38 \pm 0.05 \mathrm{~d}$ & $2.54 \pm 0.35 \mathrm{e}$ & $0.008 \pm 0.001 \mathrm{~d}$ \\
20 & Clay & $0.56 \pm 0.07 \mathrm{~cd}$ & $4.51 \pm 0.23 \mathrm{c}$ & $0.012 \pm 0.001 \mathrm{~cd}$ \\
& Loam & $0.17 \pm 0.02 \mathrm{e}$ & $3.41 \pm 0.29 \mathrm{~d}$ & $0.004 \pm 0.0004 \mathrm{e}$ \\
30 & Clay & $0.41 \pm 0.05 \mathrm{~d}$ & $6.84 \pm 0.08 \mathrm{ab}$ & $0.009 \pm 0.001 \mathrm{~d}$ \\
40 & Loam & $0.13 \pm 0.02 \mathrm{e}$ & $4.42 \pm 0.07 \mathrm{c}$ & $0.003 \pm 0.0003 \mathrm{e}$ \\
& Clay & $0.34 \pm 0.04 \mathrm{~d}$ & $8.63 \pm 0.09 \mathrm{a}$ & $0.0007 \pm 0.001 \mathrm{~d}$ \\
& Loam & $0.11 \pm 0.02 \mathrm{e}$ & $6.15 \pm 0.05 \mathrm{~b}$ & $0.002 \pm 0.0003 \mathrm{e}$ \\
\hline
\end{tabular}

Note: Different letters after means within the same column indicate significant differences by Tukey test $(P<0.05)$ 

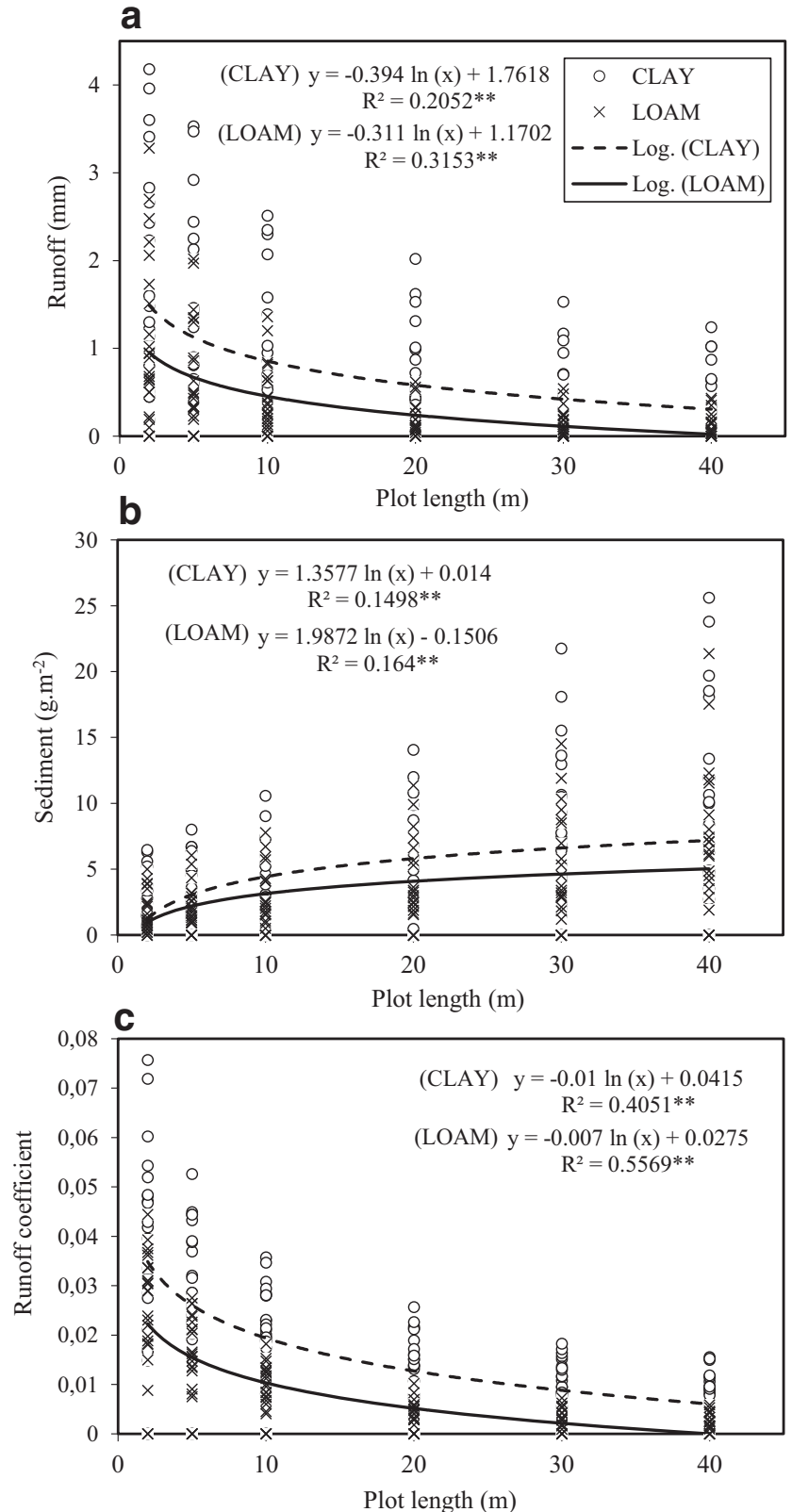

Fig. 2 Relationship between the plot length versus a runoff, b sediment, and $\mathbf{c}$ runoff coefficient on the clay- (dashed line) and loam- (solid line) textured soil. For each graph, the regression equation and the coefficient of determination $\left(R^{2}\right)$ are given. Note: ${ }^{*} P<0.05 ;{ }^{* * *} P<0.01$; ns, not significant

Sediment yield model for clayey soil texture:

Sediment $_{\text {clay }}=37.125 \times e^{-\frac{1}{2} \times\left(\frac{\mathrm{PL}-83.24}{42.5}\right)^{2}+\left(\frac{\mathrm{R}-83.9}{-34.62}\right)^{2}}$

Sediment yield model for loamy soil texture:

Sediment $\mathrm{loam}_{\text {lom }}=48.318 \times e^{-\frac{1}{2} \times\left(\frac{\mathrm{PL}-120.32}{55.2}\right)^{2}+\left(\frac{\mathrm{R}-91.88}{-38.02}\right)^{2}}$

The coefficients of determination for the Eqs. 3 to 6 were $87.2,90.0,88.1$, and $86.8 \%$, respectively.

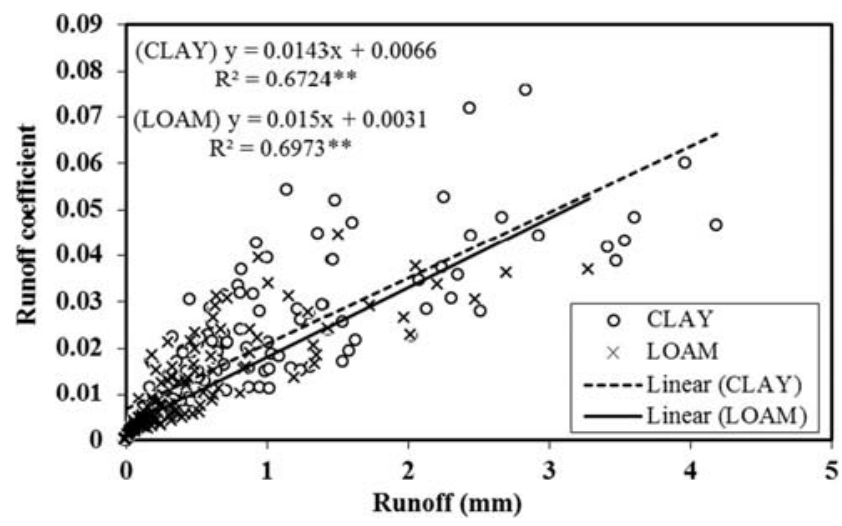

Fig. 3 Relationship between the plot length and runoff coefficient on the clay- (dashed line) and loam- (solid line) textured soil. For each line, the regression equation and the coefficient of determination $\left(R^{2}\right)$ are given. Note: ${ }^{*} P<0.05 ;{ }^{* * *} P<0.01 ;$ ns, not significant

Based on a polynomial regression analysis, predicted runoff and sediment in function of plot length and rainfall intensity on both clay and loam soil textures are presented in Figs. 4 and 5. By increasing plot length from 2 to $40 \mathrm{~m}$, in the low rainfall intensity, the differences among runoff gradually decreased, whereas in high rainfall intensity, the differences among runoff in the plot length ranging from 2 to $40 \mathrm{~m}$ were greater and severely decreased (Fig. 4). Under the similar rainfall intensity, the runoff in the clayey soil was greater than in the loamy soil for each plot length (Fig. 4). Under the similar rainfall intensity, differences of sediment yield were greater in the high rainfall intensity than in the low rainfall intensity as plot length increased. Under the similar plot length, the sediment yield in the clayey soil was greater than the loamy soil in each rainfall intensity (Fig. 5).

\section{Discussion}

\subsection{Runoff}

Besides decreasing ground cover and removing the litter layer, ground-based skidding operations normally increase soil bulk density, which can contribute to an increased overland flow through a reduction in the throughfall interception (Sosa-Pérez and MacDonald 2017; Jourgholami et al. 2018a, b). In addition, the bare mineral soil was exposed to the erosive powers of rainfall by the removal of litter and organic matter from surface soil. This phenomenon can create the "sealing" on the machine-trafficked soil (Prats et al. 2016; Jourgholami et al. 2019b), which in turn results in a reduced water infiltration rate (Sosa-Pérez and MacDonald 2017; Jourgholami et al. $2018 \mathrm{a}, \mathrm{b})$. Contrary to other studies on the scale effects on runoff and sediment, our study was conducted on machinetrafficked soils of skid trails, which presents different condition relating to water flow and soil surface. 
Fig. 4 Predicted runoff $(y, \mathrm{~mm})$ as a function of different plot lengths $(\mathrm{PL}, \mathrm{m})$ and rainfall intensities (RI, mm) on the clay- (a) and loam- (b) textured soil based on polynomial regression analysis $(n=450)$
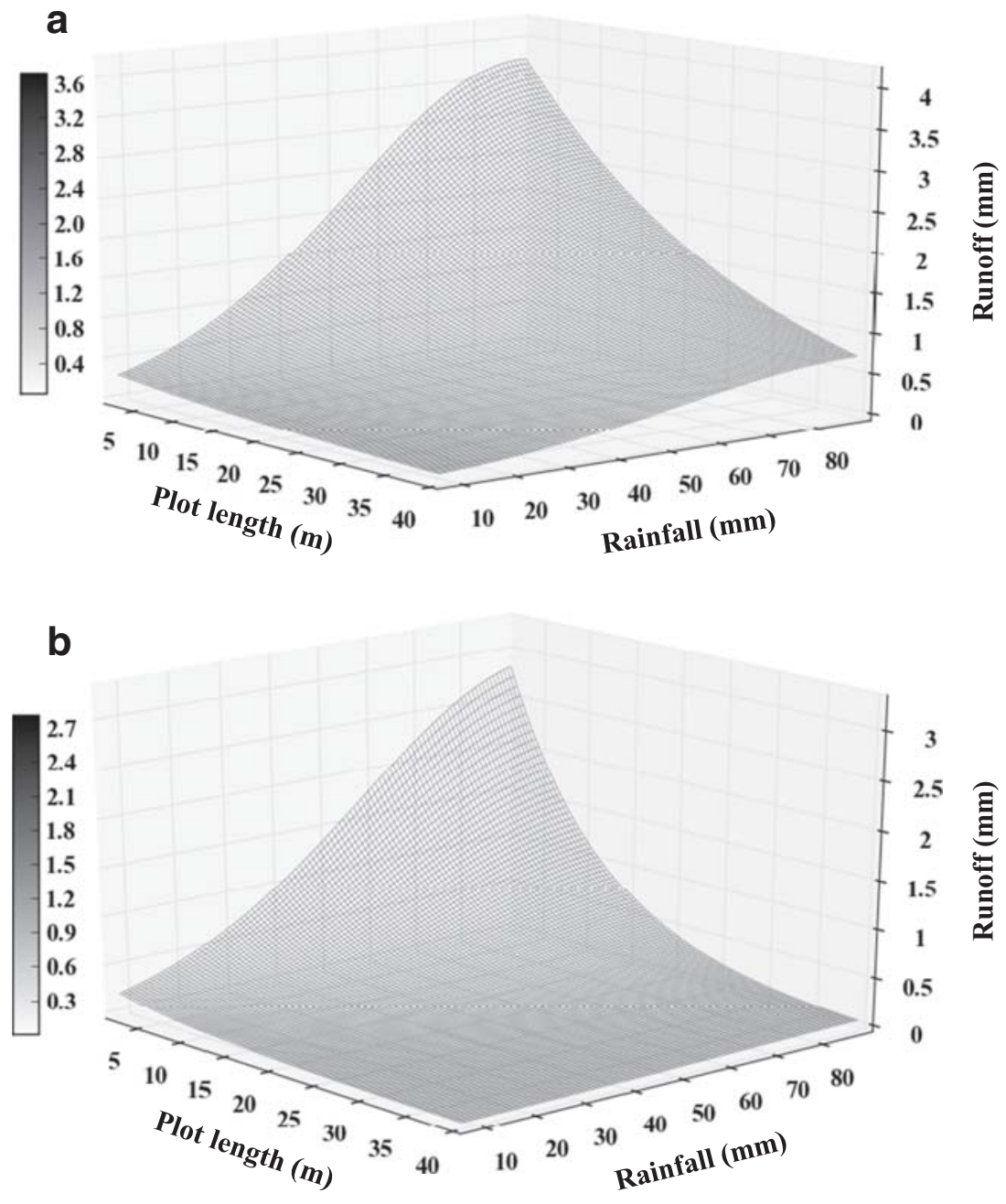

Our findings indicate that runoff decreased significantly by increasing plot length in each soil texture group. More specifically, when compared with a plot length of $2 \mathrm{~m}$, the runoff in the plot lengths of 5, 10, 20, 30, $40 \mathrm{~m}$ decreased by $22.8 \%$, $44.3 \%, 62.4 \%, 72.5 \%$, and $77.2 \%$, respectively, under the clayey soil. A similar trend of a decreasing runoff as the plot length increases was also found for the loamy soil texture. Correspondingly, Prats et al. (2016) found that runoff was up to ten times higher in the slope length of $0.5 \mathrm{~m}$ than in the slope length of $25 \mathrm{~m}$ in first year after wildfire. The decreasing trend for runoff in response to the increase in slope length could be attributed to the different effects of slope length on time of concentration. The concentration time represents the response of a watershed to a rain event and is defined as the time needed for water to flow from the outermost point in a watershed to the watershed outlet (Moreno-de las Heras et al. 2010; Zhang et al. 2018). When the rainfall duration exceeds the concentration time, surface flow normally occurs. Furthermore, in order to explain this phenomenon, Zhang et al. (2018) stated that the surface flow continuity was higher in the short plot lengths as compared with the longer ones, which resulted in a reduced concentration time, thus ultimately leading to increase runoff.

In line with the current study, Xing et al. (2016) found that runoff rates decreased as plot length increased from 5 to $20 \mathrm{~m}$, whereas runoff rates in the plot lengths of 15 and $20 \mathrm{~m}$ were not statistically different. Hence, the rate of runoff decreased moderately by increasing plot length in the range of 15 to $20 \mathrm{~m}$, which is probably due to irregularity of soil infiltration and reinfiltration processes. By increasing plot length, it is more difficult to establish the continuity between overland flows (Boix-Fayos et al. 2007; Sadeghi et al. 2013; Xing et al. 2016).

Runoff coefficient ranged from 0.001 to 0.08 in the current study. Surprisingly, runoff coefficient was very low compared with other studies both at the cropland hillslope scale ranging from 0.29 to 1.46 reported by Chen et al. (2019) and in the catchment scale ranging from 0.01 to 0.37 determined by Guastini et al. (2019). It is anticipated that one of the main reasons for this pronounced difference is that forest residuals such as tree limbs, tops, and foliage left on the skid trails can increase the ground surface roughness and thereby create 
Fig. 5 Predicted sediment $(y$, $\mathrm{mm}$ ) as a function of different plot lengths (PL, $\mathrm{m}$ ) and rainfall intensities (RI, $\mathrm{mm}$ ) on the clay(a) and loam- (b) textured soil based on polynomial regression analysis $(n=450)$
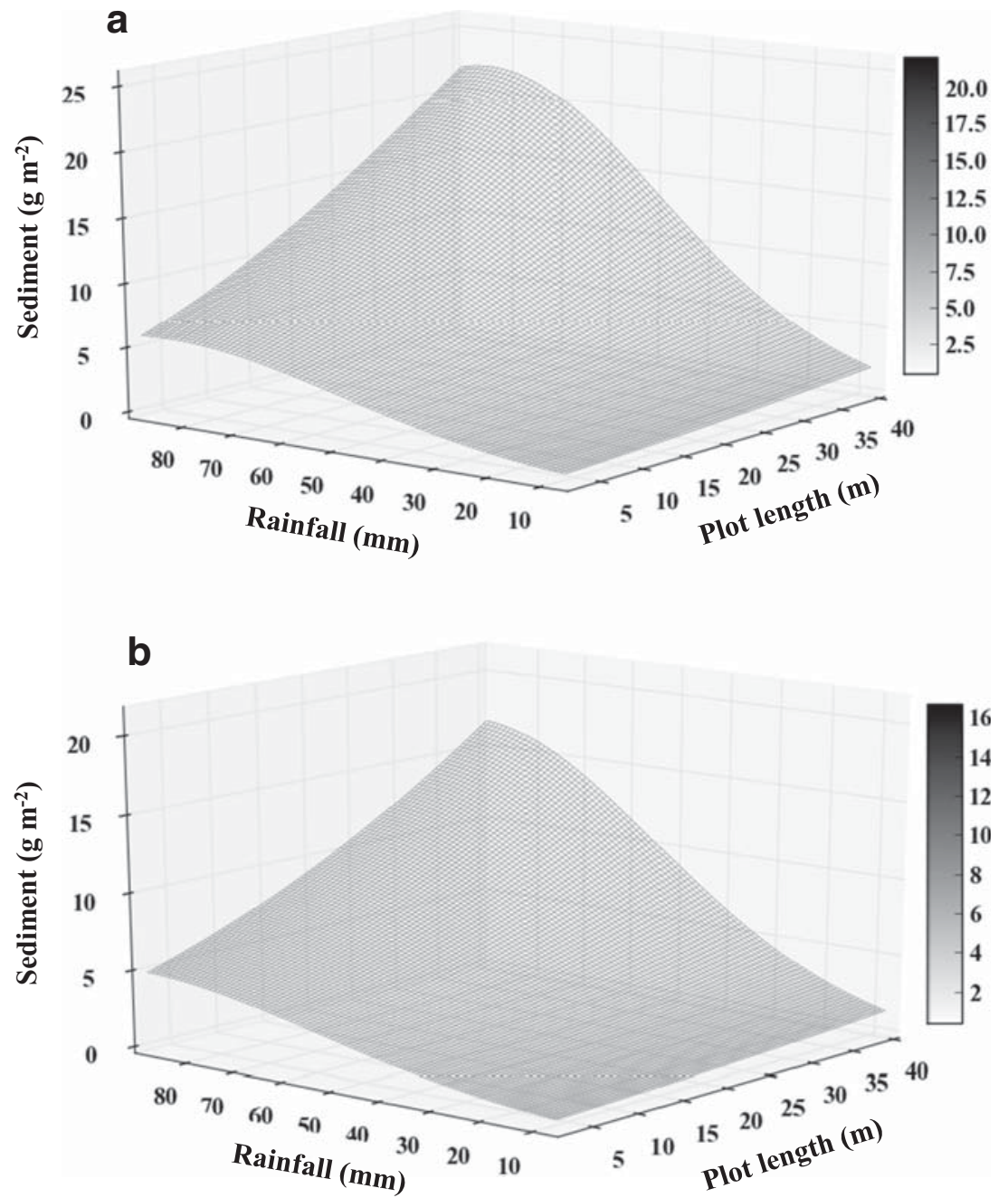

micro-dams, which in turn can intercept more easily the overland flow as compared with agricultural soils. Results of the present study also showed that the runoff coefficient logarithmically declined as plot length increased. However, the drastic reduction in runoff coefficient was observed at the plot length of $10 \mathrm{~m}$, and then gradually decreased. In contract, Parsons et al. (2006) stated that runoff coefficient declined as plot length increased. Furthermore, the feature of plot length effects depends on several factors such as rainfall intensity and characteristics, surface condition, and the intensity of soil damages during forest operations (Ghahramani et al. 2011; Jourgholami et al. 2018a).

Our study demonstrated that soil texture had a significant effect on runoff and sediment yield measured in the different plot lengths, results that are supported by Ekwue and Harrilal (2010) and Hussein et al. (2007). Our study also revealed that runoff and sediment yield were higher in the clayey soil than in the loamy one. In contrast, Wischmeier and Smith (1978) discovered that clay-textured soils had less erodibility than coarse-textured soils due to the improved aggregate stability. In our study, ground-based machine traffic (over 15 machine cycles) likely altered soil aggregates and limited their ability to resist detachment. By increasing the ease of soil particle detachment, the finer-sized particles have a greater velocity than the coarser ones, and the coarser particles can still remain in the form of aggregates (Parsons et al. 2006).

\subsection{Sediment yield}

When considering the clayey soil texture, our results demonstrated that sediment yield in the plot lengths of 5, 10, 20,30 , and $40 \mathrm{~m}$ increased by $0.24,0.52,1.04,2.09$, and 2.9 times, respectively, when compared with the sediment yield recorded in the shortest plot length of $2 \mathrm{~m}$. These results are consistent with findings from Zhang et al. (2018) stating that soil loss is significantly influenced by slope length and follows a linear positive relationship. However, the differences remain lower than the ones reported by Xing et al. (2016) where for plot lengths of $5,10,15$, and $20 \mathrm{~m}$, increases were 1.0, 11.2, 30.5, and 38.9 times greater than the sediment measured in the $1-\mathrm{m}$ plot length. By increasing plot length, the runoff velocity 
increased, which led to greater energy for transporting soil particles and caused an increased sediment yield (Prats et al. 2016; Xing et al. 2016). Bagarello and Ferro (2010) reported that soil loss showed no significant change and could even decrease, as slope length decreased.

In our study, the highest sediment yields observed in the plot length $>10 \mathrm{~m}$ could be attributed to the rill erosion process via an increased energy of runoff flow. In contrast, in the plot length $\leq 10 \mathrm{~m}$, the capability of runoff flow energy to produce rills was decreased due to a lowered carrying capacity of the eroded materials. Furthermore, Parsons et al. (2006) specified that the two most important phenomena, which affect sediment yield at the different plot scales, were as follows: limited transport distance of detached particles and a decreased runoff coefficient through an increase in plot length. Similarly, Ghahramani et al. (2011) demonstrated that sediment transport increased in the plot length from 5 to $10 \mathrm{~m}$, and decreased with hill slope $>10 \mathrm{~m}$. In line with the current study, an ideal plot length of 15-20 m for reducing runoff and sediment yield was reported by Sadeghi et al. (2013). Further, Bagarello and Ferro (2010) concluded that shortening the plot length was not an appropriate way to mitigate soil loss, since even though the rill erosion may be reduced, the rates of interrill erosion would rise following the slope length decreasing.

Our findings indicated that rainfall intensity (i.e., amount of rainfall per day) was significantly correlated to runoff and sediment yield on both clayey and loamy soil textures. These results are consistent with Kinnell (2016)'s findings, which indicated that the effect of plot length on overland flow and sediment yield could be influenced by rainfall intensity. Similarly, some studies reported that runoff and sediment yield increased as rainfall intensity increased (Kinnell 2016; Liu et al. 2015; Xing et al. 2016; Jourgholami et al. 2019a). Consistent with our study, Parsons et al. (2006) found that an increase in rainfall intensity and duration has crucial effects on the eroded sediment. By increasing rainfall intensity on both the loamy and clayey soils, sediment yield differences from plot lengths of 2 to $40 \mathrm{~m}$ were drastically increased as also reported by Xing et al. (2016). In line with the current study, Parsons et al. (2006) also found that greater rainfall intensity led to the higher runoff coefficient, which resulted in an increased sediment detachment and then a greater sediment transport.

Our hypothesis stating that soil texture and plot length may influence runoff and sediment yield during rainfall events is significantly supported by our data. One important issue that should be taken into consideration is that the prediction of runoff and sediment yield at the small plot scale cannot be projected to the large hillslope area due to scale dependency of the runoff and sediment (Parsons et al. 2004, 2006; NadalRomero et al. 2011; Kinnell 2016).

\section{Conclusion}

In the present study, the effects of plot length $(2,5,10,20,30$, and $40 \mathrm{~m}$ ) and soil texture group (clayey and loamy) were examined on runoff and sediment yield in skid trails under natural rainfall condition in a mixed deciduous forest, northern Iran. The key findings of this study are summarized as follows: (1) Plot length and soil texture significantly affected runoff and sediment yield. (2) In both soil texture classes, runoff decreased significantly, as plot length increased, whereas sediment yield increased. (3) In each plot length, runoff and sediment yield were higher in the clayey soil than in the loamy soil. (4) Under similar rainfall intensity, differences of runoff and sediment yield were greater in the high rainfall intensity than in the low rainfall intensity as plot length increased.

Our study highlights the significant effect of slope length and soil texture on runoff and sediment yield. Both runoff and sediment yield were significantly altered, as plot length increased from 2 to $20 \mathrm{~m}$. For the plots longer than $20 \mathrm{~m}$, runoff and sediment yield were less sensitive to plot length under machine-trafficked soil conditions. Indeed, the distance of $20 \mathrm{~m}$ could be applied as an ideal spacing for installing water diversion structures on skid trails to minimize the negative effects associated with surface water flow and sediment yield.

Data availability The datasets generated during and/or analyzed during the current study are not publicly available since the authors do not have permission to share data but are available from the corresponding author on reasonable request.

\section{Compliance with ethical standards}

Conflict of interest The authors declare that they have no conflict of interest.

\section{References}

Ampoorter E, De Schrijver A, De Frenne P, Hermy M, Verheyen K (2011) Experimental assessment of ecological restoration options for compacted forest soils. Ecol Eng 37:1734-1746

Bagarello V, Ferro V (2010) Analysis of soil loss data from plots of differing length for the Sparacia experimental area, Sicily, Italy. Biosyst Eng 105:411-422

Boix-Fayos C, Martinez-Mena M, Calvo-Cases A, Arnau-Rosalen E, Albaladejo J, Castillo V (2007) Causes and underlying processes of measurement variability in field erosion plots in Mediterranean conditions. Earth Surf Process Landf 32:85-101

Cambi M, Certini G, Neri F, Marchi E (2015) The impact of heavy traffic on forest soils: a review. For Ecol Manag 338:124-138

Chen B, Krajewski WF, Helmers MJ, Zhang Z (2019) Spatial variability and temporal persistence of event runoff coefficients for cropland hillslopes. Water Resour Res 55:1583-1597

de Vente J, Poesen J, Verstraeten G, Govers G, Vanmaercke M, Van Rompaey A, Arabkhedri M, Boix-Fayos C (2013) Predicting soil erosion and sediment yield at regional scales: where do we stand? Earth-Sci Rev 127:16-29 
Ekwue EI, Harrilal A (2010) Effect of soil type, peat, slope, compaction effort and their interactions on infiltration, runoff and raindrop erosion of some Trinidadian soils. Biosyst Eng 105:112-118

Etehadi Abari M, Majnounian B, Malekian A, Jourgholami M (2017) Effects of forest harvesting on runoff and sediment characteristics in the Hyrcanian forests, northern Iran. Eur J Forest Res 136:375386

Gee GW, Bauder JW (1986) Particle-size analysis. In: Klute A (ed) Methods of soil analysis, part 1. Physical and Mineralogical Methods. Soil Science Society of America, Madison, pp 383-411

Ghahramani A, Ishikawa Y, Gomi T (2011) Slope length effect on sediment and organic litter transport on a steep forested hillslope: upscaling from plot to hillslope scale. Hydrol Res Lett 5:16-20

Guastini E, Zuecco G, Errico A, Castelli G, Bresci E, Preti F, Penna D (2019) How does streamflow response vary with spatial scale? Analysis of controls in three nested Alpine catchments. J Hydrol 570:705-718

Holz DJ, Williard KWJ, Edwards PJ, Schoonover JE (2015) Soil Erosion in humid regions: a review. J Contemp Water Res Educ 154:48-59

Horn R, Vossbrink J, Becker S (2004) Modern forestry vehicles and their impacts on soil physical properties. Soil Tillage Res 79:207-219

Hussein MH, Kariem TH, Othman AK (2007) Predicting soil erodibility in northern Iraq using natural runoff plot data. Soil Tillage Res 94: 220-228

Jourgholami M, Etehadi Abari M (2017) Effectiveness of sawdust and straw mulching on postharvest runoff and soil erosion of a skid trail in a mixed forest. Ecol Eng 109:1-9

Jourgholami M, Fathi K, Labelle ER (2018a) Effects of foliage and traffic intensity on runoff and sediment in skid trails after trafficking in a deciduous forest. Eur J Forest Res 137:223-235

Jourgholami M, Khajavi S, Labelle ER (2018b) Mulching and water diversion structures on skid trails: response of soil physical properties six years after harvesting. Ecol Eng 123:1-9

Jourgholami M, Labelle ER, Feghhi J (2019a) Efficacy of leaf litter mulch to mitigate runoff and sediment yield following mechanized operations in the Hyrcanian mixed forests. J Soils Sediments 19:20762088

Jourgholami M, Ghassemi T, Labelle ER (2019b) Soil physio-chemical and biological indicators to evaluate the restoration of compacted soil following reforestation. Ecol Indic 101:102-110

Kemper WD, Rosenau RC (1986) Aggregate stability and size distribution. Klute A (Ed.), Methods of Soil Analysis. Physical and Mineralogical Properties. Part I (2nd ed.), Agronomy, vol. 9, ASA-SSSA, Madison, WI (1986) pp. 425-442

Kinnell PIA (2016) A review of the design and operation of runoff and soil loss plots. Catena 145:257-265

Liu D, She D, Yu S, Shao G, Chen D (2015) Rainfall intensity and slope gradient effects on sediment losses and splash from a saline-sodic soil under coastal reclamation. Catena 128:54-62

MacDonald LH, Stednick JD (2003) Forests and water: a state of the art review for Colorado. Colorado Water Resources Research Institute. Colorado State University, Fort Collins, CO, p 65
Moore RD, Wondzell SM (2005) Physical hydrology and the effects of forest harvesting in the Pacific Northwest: a review. J Am Water Resour Assoc 41:763-784

Moreno-de las Heras M, Nicolau JM, Merino-Martín L, Wilcox BP (2010) Plot-scale effects on runoff and erosion along a slope degradation gradient. Water Resour Res 46:W04503

Nadal-Romero E, Martinez-Murillo JF, Vanmaercke M, Poesen J (2011) Scale dependency of sediment yield from badland areas in Mediterranean environments. Prog Phys Geogr 35:297-332

Parsons AJ, Wainwright J, Powell DM, Kaduk J, Brazier RE (2004) A conceptual model for determining soil erosion by water. Earth Surf Process Landf 29:1293-1302

Parsons AJ, Brazier RE, Wainwright J, Powell DM (2006) Scale relationships in hillslope runoff and erosion. Earth Surf Process Landf 31: 1381-1393

Poesen JW, Torri D, Bunte K (1994) Effects of rock fragments on soil erosion by water at different spatial scales: a review. Catena 23:141166

Poltorak BJ, Labelle ER, Jaeger D (2018) Soil displacement during ground-based mechanized forest operations using mixed-wood brush mats. Soil Tillage Res 179:96-104

Prats SA, Wagenbrenner J, Malvar MC, Martins MAS, Keizer JJ (2016) Mid-term and scaling effects of forest residue mulching on post-fire runoff and soil erosion. Sci Total Environ 573:1242-1254

Sadeghi SHR, Bashari Seghaleh M, Rangavar AS (2013) Plot sizes dependency of runoff and sediment yield estimates from a small watershed. Catena 102:55-61

Smets T, Poesen J, Bochet E (2008a) Impact of plot length on the effectiveness of different soil-surface covers in reducing runoff and soil loss by water. Prog Phys Geogr 32:654-677

Smets T, Poesen J, Knapen A (2008b) Spatial scale effects on the effectiveness of organic mulches in reducing soil erosion by water. EarthSci Rev 89:1-12

Sosa-Pérez G, MacDonald LH (2017) Effects of closed roads, traffic, and road decommissioning on infiltration and sediment production: a comparative study using rainfall simulations. Catena 159:93-105

Stuart GW, Edwards PJ (2006) Concepts about forests and water. North J Appl For 23:11-19

Walkley A, Black IA (1934) An examination of the Degtjareff method for determining soil organic matter and a proposed modification of chromic acid titration method. Soil Sci 37:29-38

Wischmeier WH, Smith DD (1978) Predicting rainfall erosion losses. A guide to conservation planning. In: USDA agriculture handbook, Vol. 537

Xing W, Yang P, Ren S, Ao C, Li X, Gao W (2016) Slope length effects on processes of total nitrogen loss under simulated rainfall. Catena 139:73-81

Zhang X, Hu M, Guo X, Yang H, Zhang Z, Zhang K (2018) Effects of topographic factors on runoff and soil loss in Southwest China. Catena 160:394-402

Publisher's note Springer Nature remains neutral with regard to jurisdictional claims in published maps and institutional affiliations. 